Archaeological Journal

\title{
Opening Address of the Historical Section
}

\section{the Very Rev. Gloucester}

To cite this article: the Very Rev. Gloucester (1890) Opening Address of the Historical Section, Archaeological Journal, 47:1, 302-310, DOI: 10.1080/00665983.1890.10852431

To link to this article: http://dx.doi.org/10.1080/00665983.1890.10852431

$$
\text { 曲 Published online: } 15 \text { Jul } 2014 .
$$

Submit your article to this journal 중

Q View related articles 두 


\section{OPENING ADDRESS OF THE HISTORICAL SECTION.1}

By the VERY REV. THE DEAN OF GLOUCESTER.

Gloucester-Its name and many coloured memories sends us back to the early years of the Christian Era. During the Roman occupation it was an important Frontier City. I have been taken over " the Gloucester of the last decade of the xix century" by a distinguished local antiquary, with the sole aid of Viollet le Duc's sketch map of the Praetorian camp at Rome, for Roman Gloucester was strictly laid out on the same plan. Saxon (English) Gloucester - the city of Alfred's daughter, Atthelflaed, somewhile Lady of the Mercians, the city of Athelstan and of Harthacnut, the home so often lived in by the saintly confessor king and his great Theigns such as Godwine Leofric and Harold-was built exactly on the same lines as the old fortified camp. The streets of mediæval and modern Gloucester, one and all still follow the lines of that great fortified camp of Claudius and Hadrian built upon the banks of the Severn waters over against the wild and turbulent tribes of the Silures of Southern Wales, that great place of arms which so soon became the chief city and emporium of all the fair Severn lands.

The Roman city is with us still, beneath our feet, a spade or pickaze can, at this moment, be scarcely used for a few minutes in our city without disclosing the mighty wall built by the Italian conqueror, the vast substructure of a temple, or of a great municipal building, or the scarcely discoloured mosaics of a pavement, where once, stranger Italian wanderers worshipped, worked, and walked.

With this cultured many sided life, in which men and women, boys and girls of an old world shared-men and

${ }^{1}$ Read at the Annual Meeting of the Institute, at Gloucester, August 14th, 1890. 
women who might have talked with St. John-I have not to deal with specially in this little study, my work belongs to another and a later age. Suffice it to say that the Roman life, with its constant passing to and fro between Italy and the great southern cities, with its legionaries and civic functionaries, with all its brilliant surroundings-costly dress, splendid houses, magnificent temples, gardens, art in its highest developmentsomewhat abruptly came to an end in the beginning of the fifth century. 409 is a good date. The strange appearance of clouds of barbarians from the North and East threatened all the provinces, and even Italy and sacred Rome. All the outlying legions were recalledand what may be termed the story of Roman life in Britain came to an end. Then settled over the Island and our Gloucester-for with Gloucester we have to do to-day -an impenetrable mist. What happened to our prosperous city and to the county dotted over with beautiful homesteads, and with not a few palace-like residences like the Chedworth villa, or the far more lordly and magnificent house of Woodchester, only some ten miles distant? It seems as though Britain after the legions left was divided out into numerous little kingships. In the final crash which took place in our part of Britain some 160 years later, Bath, Cirencester, and Gloucester had each their petty king. We have a few scraps of legendary history, but nothing dependable. Probably the old Roman provincial life went on much as before, though on a narrower and less magnificent scale. Then came the end. Through the dim mist which had settled over our city and county after 409 for a century and a-half, we catch sight of a terrible battle between the British Provincials and the English invaders. These were West Saxons under Ceawlin. At the battle of Deorham the three British kings - the successors of the Roman Governorsthe three kings of Bath, Cirencester, and Gloucester, were slain, and no doubt directly after, these cities became the spoil of the invading army of Ceawlin. The battle and rout took place in 577. The native British rule had lasted in Gloucester about 160 years. Deeper and darker now did the mist settle over our city. For some 100 years we are absolutely in ignorance what happened to 
us. Some of the great Roman cities of Britain which fell at that period were simply sacked and deserted, and remained empty and desolate for a hundred or more years. This we know was the fate of Deva (Chester) our neighbour Bath (Aquae-Solis). Others such as Anderida in the Pevensey district in Sussex have lain still and desolate now for 1350 years. Of this once great city portions of the walls and massive towers still remain. But since the dread day when the Saxons stormed and sacked the once fair city of Anderida, no human being has found shelter there. Was Gloucester like Deva (Chester) Bath and Anderida-desolate and empty for a century, or was it dwelt in by the conqueror? If so, no doubt the sites of the Pagan temples and new Christian churches were occupied by the wild worship of Woden and Thor, for we must not forget that this conquest meant the uprooting of Christianity.

Gloucester emerges out of the thick dark mist some 100 years later.

The following table, shewing some of the principal events (with approximate dates) which had Gloucester for their scene, will be useful :-

Honorius, A.D.409, Evacuation of South Britain by Romans.

168 years of Petty (probably native British) Kings. A.D. 577, Ceawlin, the West Saxon, slays the British King Coninagil at Deorham. Darkness for a century. King Penda of Mercia.

King Ethelred.

Osric, $\quad$ Oswald (nephews of Ethelred.)

A.D. 689, founded Gloucester Abbey. founded Pershore Abbey, killed by Osric, A.D. 729.

A.D. 689-823. Osric's foundation was an abbey of nuns. Ladies of the highest dignity were abbesses, such as Eadburga, Lady of Mercia.

The last was Eva, of Mercia, widow of King Wulphere, of Mercia, 
A.D. 823-1022. Under Beornwulph, King of Mercia. (The nuns are said to have fled in the confusion of Mercia's troubles). St. Peter's Abbey at Gloucester became the home of secular canons.

A.D. 918. St. Oswald's Priory, close to the Severn, founded by \&thelflaed, daughter of King Alfred, Lady of the Mercians, at present St. Catharine's Church, Gloucester.

A.D. 940. Athelstan died in Gloucester; buried at Malmesbury.

A.I. 1022-1539. Benedictines established under Wulfstan, Bishop of Worcester.-1. Abbot Eadric (the waster of goods). 2. Abbot Wulfstan (monk of Worcester). 3. Abbot Serlo (monk of Mont St. Michel in peril of the See.)

The Gemots of Gloucester are now endless. Among the most notable are :-

A.D. 1041. Gemot under Harthacnut, midwinter, at this Gemot the king sold the bishopric of Durham.

A.D. 1043. Gemot under Edward the Confessor decided upon the confiscation of the goods of his mother, Lady Emma.

A.D. 1051. Gemot of Gloucester on subject of Edward's favouring Normans, especially Count Eustace of Boulogne.

A.D. 1052. Head of Welch rebel prince brought to King Edward the Confessor at, Gloucester Gemot.

As a rule when William the Conqueror was at peace and in England he kept his Christmas feast at Gloucester.

A.D. 1085-6. Gemot under William the Conqueror was held which ordered Domesday Book to be drawn up.

A.D. 1093. At this Gemot Robert Duke of Normandy challenged William Rufus. Mr.Freeman says," In the reign of William Rufus almost everything that happened at all somehow contrived to happen at Gloucester."

A.D. 1092. Anselm was appointed Archbishop of Canterbury against his will by William Rufus, lying (apparently) sick to death.

A.D. 1100. The death of William Rufus by an arrow was prophesied by Fulcherius, Abbot of Shrewsbury, in a sermon in Gloucester. This same year Serlo's Abbey, well-nigh completed, was consecrated.

A.D. 1216. Henry III. crowned in Gloucester Abbey.

A.D. 1378, Richard II. held the famous Parliament VOL. XIVII 
within the Abbey walls, in which the House of Commons won to itself the control of the finances of the nation.

A.D. 1533. Henry VIII. spent eight days with Queen Anne Boleyn in Gloucester Monastery.

Gloucester Cathedral awakens many memories-stirs up many and varied thoughts. Its very name sends us back before the days of Claudius, the Emperor, before the Christian Era. In England a few natural objects, a few ancient cities, like London and Gloucester, still retain names older than the Roman, the Angle, or the Saxon. So old is the famous first syllable "Glou," the storied city's real name, that as yet our most learned philologists hesitate about its real meaning. We think probably Glou-Cestra signifies "The Fair City," but it is only at best a surmise. At the time of the Conquest the city of Gloucester occupied the third position in the realm. London and Winchester and Gloucester seem to have been the three official meeting places for the King and the great council of the nation.

\section{* * * * *}

Look at the pile a moment from the Cloister Garden. Observe its twin unmistakeable Norman towers, flanking the tall north transept. They remind us of the invariable feature of these transepts in all the vast Norman churches from scarred mutilated Fécamp to the serene beauty of Canterbury. They tell us-though comparatively little else tells us in this fair view from the Cloister Gardenthat the same people built and planned this great church as built and planned Fécamp Abbey and Canterbury and many other such lordly piles.

-. Look a moment at the round-headed windows along the nave. They tell, too, the same story of their Norman parentage as do the transept towers, though the mullions of these windows help to disguise their real characterspeaking as they do of another age and of a different inspiration. Then the great windows of the transept, the elaborate batilements, the exquisite tracery of the cloister windows, speak of the new spirit of architecture which arose in the days of the third Edward-arose, we think, in these sacred walls, and suggested a new school of Gotlic architecture which for some two centuries was 
the favourite style of English builders-the well-known Perpendicular. Then the great central tower, which marks the slight changes which a hundred years or more brought with it in this style, and tells us how men built and designed in the stormy epoch of the War of the Roses. The eye for a minute leaves the great church. Nestling close under the transept towers is a large plain massive building, quite unadorned, unmistakeably Norman of an early date. In those old grey walls, probably somewhat enriched about three or four years later, the Conqueror sat, and held that deep speech with his Witan which resulted in the compilation of Domesday Book.

What a solemn changeless witness to English history is our great church, with its varied schools of architecture, one succeeding the other; with its many traditions, withits storied coloured glass, its under church, its great chapter room. How many scenes of the history of England have been acted in these sacred enclosures, such as the death of Saxon Athelstan, the anxious day passed by the Confessor when the conflict between his Norman friends and the English host under Godwin was at its height. The forms of Edward and Earl Godwin, of Harold and the Norman Count Eustace of Boulogne, of Tostig and Siward, of Gurth and Stigand, seem to pass before us. So much of these stirring scenes passed here. The under church-many of us think still-was built in the Confessor's days. Then William the Conqueror, not once or. twice, wore his crowned helm as he presided in the old chapter room over his barons at the great Christmas feast. I should think all those mighty men-of-war-the halfbrothers Odo of Bayeux and Robert de Mortain, William FitzOsbern, Roger de Montgommeri, Geoffrey de Mowbrai, Roger Bigod, Gundulf of Rochester, and greatest of all, Lanfranc, the loved friend and counsellor, the archbishop -household words with many of us-many times have held deep speech with their stern lord, William, have feasted in the refectory, and have prayed in the church; and taken counsel in this chapter room of the great cathedral.

Some of them and their sons are buried, we believe, beneath the chapter room floor. Robert the Crusader, the Duke of Normandy, the unhappy eldest born of the 
Conqueror, we know, lies in front of the high altar. William Rufus spent not a little of his time here. It was in the halls of Gloucester, when he lay sick unto death, that he thrust the staff of the Archbishopric of Canterbury into the unwilling hands of Anselm, who received his hurried consecration in the neighbouring minster. The nave-save that the present stone roof replaced the older one of wood in Henry II.'s dayswas, when Anselm was consecrated, very much as we see it now, only a little whiter and more new looking. Our Minster Church, among other stirring scenes and stately ceremonials, witnessed the coronation of King Henry III. and the sadder sight of the somewhat hurried obsequies of King Edward II., who lies beneath the exquisite canopied tomb hard by the high altar.

This same royal tomb received more ornamentation at the hands of King Richard II., who, curiously enough, round the massive Norman pillars which overshadowed the beautiful tomb of Edward II. blazoned his favourite device of the white harte couchant. The same device -we find it on the two contemporary portraits of that monarch, worked on his robe, one of which is in that most solemn sanctuary of Westminster Abbey, and the other on the famous Dyptich of Lord Pembroke at Wilton House -appears to have been the cognizance of his mother, widow of the Black Prince, once known as the Fair Maid of Kent. It was in Gloucester that this King (Richard II.) held the famous "Money" Parliament. Tradition has it that the Commons sat in the Chapter Room, and the King $\because$ nd the Peers met in the beautiful guest chamber of the Deanery-the Deanery for 200 years the Abbot's Camera -then the dwelling-house of the Prior -the lodging must this Deanery have often been of many of the kings of England - the scene of many a stirring event in the History of our County.

Returning to the tomb of Edward II., there is a special interest surrounding this splendid canopied tomb and its beautiful recumbent effigy of the murdered King. The neighbouring Abbeys of Bristol, Malmesbury, and Kingswood refused to give the body of Edward burial within their walls, fearing the resentment of Queen Isabella. The fearless Abbot of Gloucester, Thoky, cared nothing for the 
wicked Queen or the unpopularity of the dead King, but gave the dead Edward a royal funeral, and laid the body tenderly and reverently close to the high altar of his Abbey. Within a very short space of time a reaction set in. To the tomb of Edward, the unpopular murdered monarch, flocked crowds of pilgrims, each with their offerings more or less costly. Soon we hear that through these offerings the treasury of the Monastery became so enriched that had the Monks pleased they could have rebuilt the whole of the vast Abbey. Among the more costly of the earlier gifts at the tomb were "ships of gold," " a gold cross with a piece of the true Cross set in it," "a ruby," \&c., \&c. These precious offerings were from King Edward III., Queen Philippa, the Black Prince, and others. With this well-stored treasury the great architect-Abbots Wigmore, Stanton, and Horton, recast the whole east limb of the Cathedral, including the lantern, the two transepts, and the choir and the noble and perfect cloister. They prepared, too, for the raising and rebuilding in another generation of the present matchless tower. The exquisite Lady Chapel was the work of nearly a century and a-half later. The costly and splendid work of the three great Architect-Abbots was commenced 1327. The south transept was completed by 1337 , and is by several years the oldest piece of Perpendicular work we are cognizant of. The choir-its superb vaulting, its soaring roof, its matchless window-was finished before 1350 , before which date the exquisite glass which nearly in its entirety still delights and charms us, was all fixed in its place. The cloisters, north transept, and the rest of the stalls were all finished before the end of the fourteenth century. The great east window, the framework and mullions of which contain a few more square yards than the great York window, and is, therefore, the largest in England, and as far as I know the largest in the world, has a peculiar historical interest. Mr. Winston, one of the greatest experts in ancient stained glass, after careful investigation into the undoubted genuine heraldic shields, and into the peculiar character of the colours used-after, too, calling attention to the stone framework being an early but decided example of the Perpendicular style and the stained glass 
a pure example of the Decorated, taking these three points especially into consideration :- $(1)$, the date of the armorial bearings (some twelve undoubtedly genuine ones are in the window); (2), the sort of colours used; (3), the difference in styles between the stone framework and the stained glass, Mr. Winston unhesitatingly dates the completion of the window before A.D. 1350 , and shows us that we have here a group of the coats of arms of the army of heroes connected most certainly in some way with this county and engaged in the campaign of Edward III., which is famous for the battle of Cressy. We should now speak of this glorious window, simply matchless in colour and size, as a memorial of the battle of Cressy. The "Cressy" window we should now term it.

I have forborne-in this little sketch of historical memories, to touch upon-what will be far more efficiently handled by one of your members who has honoured the gathering with his presence, and whose great European reputation will enable him to speak with far more authority than any to which I could pretendon the peculiarly inventive character of the three great building Abbots-Wigmore, Stanton, and Horton, and their immediate predecessor Thoky. He will, in another department of our work, point out to us how these great builders not only introduced, but most probably invented, Perpendicular architecture, that form of Gothic so loved in England-almost peculiar to our island-how that graceful and perfect form of roofing usually called by the name of fan-tracery first appeared in the matchless cloister of Gloucester. My task has been to evoke a few of the great historic memories connected with this storied pile. 